\title{
A Brief Rationale for MMT Arguments
}

\author{
Yasuhito Tanaka \\ Faculty of Economics, Doshisha University \\ Kamigyo-ku, 602-8580, Kyoto, Japan.
}

Received: November 6, 2021 Accepted: November 26, 2021 Published: December 10, 2021

doi:10.5296/iss.v9i2.19160ＵRL: http://dx.doi.org/10.5296/iss.v9i2.19160

\begin{abstract}
In this note we examine MMT (Modern Monetary Theory) arguments by a simple macroeconomic model without microeconomic foundation. Mainly we will show the following results. 1) In the underemployment case the national income is determined by the budget deficit. 2) In the full employment case we can define the budget deficit which is necessary and sufficient to achieve full employment. 3) The excessive budget deficit causes inflation. 4) We need budget deficit to achieve and maintain full employment under economic growth. 5) We can recover recession by the budget deficit which is larger than that when full employment is maintained. Also, we show that the budget deficit equals the increase in the savings between generations.
\end{abstract}

Keywords: MMT, Budget deficit, Economic growth

JEL Classification: E12, E24. 


\section{MlMacrothink}

\section{Introduction}

In some previous studies (Note 1) we have examined the arguments for fiscal policy from the perspectives of Lerner's (1943, 1944) Functional Finance Theory and MMT (Modern Monetary Theory, Wray (2015), Mitchell, Wray and Watts (2019), Kelton (2020) (Note 2) by several models, a static model, an overlapping generations model (according to Otaki, 2007, 2009,2015 ) of perfect competition under constant returns to scale technology, an overlapping generations model of perfect competition under decreasing returns to scale technology with positive profits, an overlapping generations model of monopolistic competition (oligopoly with differentiated goods) with positive profits; with or without pay-as-you-go pensions for the older generation consumers, with or without unemployment insurances, with or without consumption in the childhood period before the younger (working) period. In these models, we studied the problems caused by budget deficits from the perspectives of Functional Finance Theory and MMT based on the microeconomic foundations of consumer and firm behavior: utility maximization by consumers under budget constraint and profit maximization by firms. In this note, on the other hand, we will provide a discussion of the effects of budget deficits using a very simple macroeconomic model without the microeconomic foundations.

Mainly we will prove the following results.

1) Underemployment case

- The real national income is determined by the budget deficit given the marginal propensity to consume, the constant part of consumption function and tax. (Proposition 1)

- The real national income is determined by the budget deficit given the marginal propensity to consume, the constant part of consumption function and the fiscal spending. (Proposition 2)

If full employment is not achieved, the independent variable is the budget deficit, and the national income and the savings are determined by the budget deficit not that the savings of consumers determine the budget deficit.

2) Full employment case

- We can define the budget deficit which is necessary and sufficient to achieve full employment given the propensity to consume, the constant part of the consumption function and the tax (or the fiscal spending) by the full employment real national income and the investment. (Proposition 3 and 4)

- If we achieve full employment under balanced budget, the constant part of the consumption function must take a specific value. (Proposition 5)

The results in 1) and 2) mean that insufficient budget deficit (the budget deficit which is smaller than the budget deficit necessary and sufficient to achieve full employment) causes recession with involuntary unemployment.

3) Inflation 


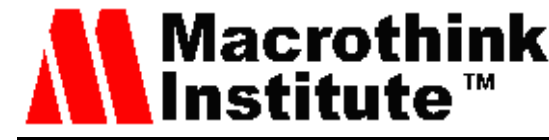

The excessive budget deficit (the budget deficit which is larger than the budget deficit necessary and sufficient to achieve full employment) causes inflation. (Proposition 6)

4) Economic growth with full employment

We need budget deficit to achieve and maintain full employment under economic growth. (Proposition 7)

\section{5) Recovery from recession}

In order to recover full employment from recession we need budget deficit larger than that when full employment is maintained. (Proposition 9)

Also, we will show that the budget deficit equals the increase in the savings between generations (Proposition 8). Although our model is not an overlapping generations model, one generation of consumers will consequently leave savings for the next generation.

We think that the essence of MMT with respect to fiscal policy lies in the following two points.

- "Financial resources is not necessary for fiscal spending" or "Taxes are not a source of revenue for fiscal spending"

From a macroeconomic point of view, fiscal spending has the role of increasing the demand for goods, while taxes have the role of reducing disposable income of consumers and thus reducing demand. In order to achieve full employment and stable growth without inflation, an appropriate balance between the size of fiscal spending and taxes is necessary. We do not need taxes for fiscal spending

- There is no need to pay off government debt with taxes.

The central bank could just buy up all the government bonds. This might have the effect of lowering interest rates, but it would not directly increase demand for goods and would not cause high rates of inflation, because people would not have more assets or income (unless the central bank bought them at a price above face value). If it is implemented during a recession, it will not cause low inflation either. Government bonds are money in the same broad sense as bank term deposits ("liquidity in the broad sense"), and the central bank's purchase of government bonds does not increase the money supply in that sense, so from the point of view of the quantity theory of money there is no inflation.

\section{Analyses}

\subsection{Underemployment Case}

We consider a simple macroeconomic model without the microeconomic foundations of consumers and firms. Let $Y_{f}$ be the full employment real national income, and $Y$ be the actual real national income. We assume underemployment, that is, $Y<Y_{f}$. The price of the goods is one. The consumption function is

$$
C=C_{0}+\alpha(Y-T) .
$$




\section{Macrothink}

$C$ is the real consumption. $C_{0}$ is the constant part of $C . T$ is the tax. $\alpha$ is the marginal propensity to consume. $0<\alpha<1$. The national income is

$$
Y=C+G=C_{0}+\alpha(Y-T)+I+G \text {. }
$$

$G$ is the real government expenditure. $I$ is an investment of firms. No detailed analysis of investment is given. We assume that it is constant. From this

$$
(1-\alpha)(Y-T)=G-T+I+C_{0},
$$

or

$$
(1-\alpha)(Y-G)=\alpha(G-T)+I+C_{0} .
$$

Therefore,

$$
Y=\frac{G-T+I+C_{0}}{1-\alpha}+\frac{\alpha}{1-\alpha} T
$$

or

$$
Y=\frac{\alpha(G-T)+I+C_{0}}{1-\alpha}+G
$$

These mean the following results.

Proposition 1. The real national income $Y$ is determined by the budget deficit $G-T$ given $\alpha, C_{0}$ and $T$.

Proposition 2. The real national income $Y$ is determined by the budget deficit $G-T$ given $\alpha, C_{0}$ and $G$.

\subsection{Full Employment Case}

$Y_{f}$ is not a variable, but constant. If full employment is achieved, (1) is rewritten as

$$
Y_{f}=C_{0}+\alpha\left(Y_{f}-T\right)+I+G \text {. }
$$

This means

$$
G-T=(1-\alpha)\left(Y_{f}-T\right)-I-C_{0}
$$

Thus, we find

Proposition 3. The budget deficit which is necessary and sufficient to achieve full employment given $\alpha, C_{0}$ and $T$ is

$$
(1-\alpha)\left(Y_{f}-T\right)-I-C_{0}
$$

The results in Proposition 1, 2, 3 mean that insufficient budget deficit (the budget deficit which is smaller than the budget deficit necessary and sufficient to achieve full employment) causes recession with involuntary unemployment.

(2) is rewritten as follows,

$$
G-T=\frac{(1-\alpha)\left(Y_{f}-G\right)-I-C_{0}}{\alpha}
$$




\section{MIN Macrothink}

This means

Proposition 4. The budget deficit which is necessary and sufficient to achieve full employment given $\alpha, C_{0}$ and $G$ is

$$
\frac{(1-\alpha)\left(Y_{f}-G\right)-I-C_{0}}{\alpha}
$$

Also we find

Proposition 5. If full employment is achieved under balanced budget $(G-T=0), C_{0}$ must be

$$
(1-\alpha)\left(Y_{f}-T\right)-I=(1-\alpha)\left(Y_{f}-G\right)-I .
$$

If the budget deficit is smaller than the value in (2) and (3), there will be underemployment, or the recession with involuntary unemployment.

\subsection{Inflation by Excessive Budget Deficit}

Let $p$ be the price of the good. Suppose that the nominal national income is $p Y$, the nominal government expenditure is $G^{\prime} . C_{0}$ and $T$ do not change, and full employment is achieved. Then, we have

$$
p Y_{f}=C_{0}+\alpha\left(p Y_{f}-T\right)+I+G^{\prime}
$$

From this

$$
G^{\prime}-T=(1-\alpha)\left(p Y_{f}-T\right)-I-C_{0}
$$

Comparing (2) and (5), we get

$$
G^{\prime}-T-(G-T)=(1-\alpha)(p-1) Y_{f} .
$$

Thus, $p>1$ when $G^{\prime}-T>G-T$.

Alternatively we assume that the tax is decreased to $T^{\prime}$, and $G$ does not change. Then, we have

$$
p Y_{f}=C_{0}+\alpha\left(p Y_{f}-T^{\prime}\right)+I+G .
$$

This means

$$
\alpha\left(G-T^{\prime}\right)=(1-\alpha)\left(p Y_{f}-G\right)-I-C_{0} .
$$

Comparing this with (3) yields

$$
\alpha\left(G-T^{\prime}\right)-\alpha(G-T)=(1-\alpha)(p-1) Y_{f} .
$$

$p>1$ when $G-T^{\prime}>G-T$. Therefore, we have shown the following result.

Proposition 6. The excessive budget deficit causes inflation.

As for the inflation process, we can think of a story in which excess demand for goods generates excess demand for labor, which raises the nominal wage rate, which in turn raises the prices of the goods. 


\subsection{Economic Growth with Full Employment}

We can assume that $C_{0}$ is financed by the savings of the previous generation consumers. If the economy grows between generations at the rate of $\gamma-1>0$ with full employment,

$$
C_{0}=\frac{1}{\gamma}\left[(1-\alpha)\left(Y_{f}-T\right)-I\right]>0 .
$$

Investment and tax also increase at the rate of $\gamma-1$. Then, from (2)

$$
G-T=\frac{\gamma-1}{\gamma}\left[(1-\alpha)\left(Y_{f}-T\right)-I\right]>0 .
$$

This means

Proposition 7. We need budget deficit to achieve and maintain full employment under economic growth.

\subsection{The Budget Deficit and Savings by Consumers}

(6) implies the following results.

Proposition 8. The budget deficit equals the increase of the savings between generations.

Let us consider generally. Let $\bar{Y}$ be the real national income in the previous period (Period 0), $Y$ and $p$ be the real national income and the price in this period (Period 1). The savings in Period 0 is equal to

$$
(1-\alpha)\left(\bar{Y}-\frac{1}{\lambda} T\right)-\frac{1}{\lambda} I
$$

and the savings in Period 1 is

$$
(1-\alpha)(p Y-T)-I \text {. }
$$

The price in Period 0 is normalized to 1 . From

$$
p Y=C_{0}+\alpha(p Y-T)+I+G,
$$

and

$$
C_{0}=(1-\alpha)\left(\bar{Y}-\frac{1}{\lambda} T\right)-\frac{1}{\lambda} I
$$

the budget deficit in Period 1 is obtained as follows.

$$
G-T=(1-\alpha)(p Y-T)-I-C_{0}=(1-\alpha)(p Y-T)-I-\left[(1-\alpha)\left(\bar{Y}-\frac{1}{\lambda} T\right)-\frac{1}{\lambda} I\right]
$$

Therefore, Proposition 8 holds whether we have full employment or not, whether we have inflation or not.

2.6 Recovery from Recession

Suppose that a recession is caused by an insufficient budget deficit in Period 0, and full 
employment is restored in Period 1. The price is constant at $1 . \bar{Y}<Y_{f}$, and $C_{0}$ is the same as that in the previous case. Let $G^{\prime}$ and $T^{\prime}$ be the fiscal spending and the tax in Period 1.

Then, in Period 1

$$
Y_{f}=C_{0}+\alpha\left(Y_{f}-T^{\prime}\right)+I+G^{\prime}
$$

From this

$$
G^{\prime}-T^{\prime}=(1-\alpha)\left(Y_{f}-T^{\prime}\right)-I-\left[(1-\alpha)\left(\bar{Y}-\frac{1}{\lambda} T\right)-\frac{1}{\lambda} I\right]
$$

If full employment is achieved in Period 0, and the fiscal spending and the tax in Period 1 are $G$ and $T$, we have

$$
G-T=(1-\alpha)\left(Y_{f}-T\right)-I-\left[(1-\alpha)\left(Y_{f}-\frac{1}{\lambda} T\right)-\frac{1}{\lambda} I\right]
$$

If $T=T^{\prime},(8)$ and (9) mean

$$
G^{\prime}-T^{\prime}-(G-T)=(1-\alpha)\left(Y_{f}-\bar{Y}\right)>0
$$

On the other hand, if $G=G^{\prime}$, (8) and (9) mean

$$
\alpha\left[G^{\prime}-T^{\prime}-(G-T)\right]=(1-\alpha)\left(Y_{f}-\bar{Y}\right)>0
$$

(10) implies that the budget deficit when recession is recovered by an increase in the fiscal spending is larger than the budget deficit when full employment is maintained. (11) implies that the budget deficit when recession is recovered by the tax reduction is larger than the budget deficit when full employment is maintained. We have shown

Proposition 9 In order to recover full employment from recession we need budget deficit larger than that when full employment is maintained.

\section{Conclusion}

We have shown the main statements of MMT (Modern Monetary Theory) and Functional Finance Theory by a simple macroeconomic model. The purpose of this note was to show that the basic propositions of MMT can be established by simple models without the use of complicated ones including microeconomic foundations.

\section{Acknowledgments}

We thank the reviewers for their thorough reviews and highly appreciate the comments and suggestions, which significantly contributed to improving the quality of the publication. This work was supported by JSPS KAKENHI Grant Number 18K01594 in Japan.

\section{References}

Kelton, S. (2020). The Deficit Myth: Modern Monetary Theory and the Birth of the People's Economy. Public Affairs. 


\section{Macrothink}

Lerner, A. P. (1943). Functional finance and the federal debt. Social Research, 10, 38-51.

Lerner, A. P. (1944). The Economics of Control: Principles of Welfare Economics. Macmillan.

Mitchell, W., Wray, L. R., \& Watts, M. (2019). Macroeconomics. Red Globe Press.

Mochizuki, S. (2020). A book understanding MMT (in Japanese, MMT ga yokuwakaru hon). Shuwa System.

Morinaga, K. (2020). MMT will save Japan (in Japanese, MMT ga nihon wo sukuu). Takarajimasha.

Nakano, A. (2020). A book to understand the key points of MMT (in Japanese, MMT no pointo ga yokuwakaru hon), Shuwa System.

Otaki, M. (2007). The dynamically extended Keynesian cross and the welfare-improving fiscal policy. Economics Letters, 96, 23-29. https://doi.org/10.1016/j.econlet.2006.12.005

Otaki, M. (2009). A welfare economics foundation for the full-employment policy. Economics Letters, 102, 1-3. https://doi.org/10.1016/j.econlet.2008.08.003

Otaki, M. (2015). Keynesian Economics and Price Theory: Re-orientation of a Theory of Monetary Economy. Springer. https://doi.org/10.1007/978-4-431-55345-8

Park, S. (2020). The fallacy of fiscal collapse (in Japanese, Zaisei hatanron no ayamari). Seitosha.

Shimakura, G. (2019). What is MMT? (in Japanese, MMT towa nanika), Kadokawa Shinsho.

Tanaka, Y. (2021a). Mathematical model of MMT with profit return under monopolistic Competition. Journal of Social Science Studies, 8, 65-87.

https://doi.org/10.5296/jsss.v8i2.19073

Tanaka, Y. (2021b). An elementary mathematical model for MMT (Modern Monetary Theory), Research in Applied Economics, 13, 1-20. https://doi.org/10.5296/rae.v13i3.18989

Tanaka, Y. (2021c). Very Simple Mathematical Model of MMT (Modern Monetary Theory). Business and Economic Research, 11, 78-87. https://doi.org/10.5296/ber.v11i3.18983

Wray, L. R. (2015). Modern Money Theory: A Primer on Macroeconomics for Sovereign Monetary Systems (2nd ed.). Palgrave Macmillan.

\section{Copyright Disclaimer}

Copyright for this article is retained by the author(s), with first publication rights granted to the journal.

This is an open-access article distributed under the terms and conditions of the Creative Commons Attribution license (http://creativecommons.org/licenses/by/3.0/). 